\title{
EFEKTIFITAS EKSTRAK DAUN KEMBANG BULAN (Tithonia diversifolia) TERHADAP GAMBARAN HISTOPATOLOGI PANKREAS PADA TIKUS YANG DIINDUKSI ALOKSAN
}

\author{
Rondius Solfaine ${ }^{1}$, Dian Ayu Kartika Sari ${ }^{1}$, Anisa Novia Wati ${ }^{1}$, Roeswandono ${ }^{1 *}$ \\ ${ }^{1}$ Fakultas Kedokteran Hewan, Universitas Wijaya Kusuma Surabaya \\ *Email : atmajaros@uwks.ac.id
}

\begin{abstract}
This study was conducted to determine the histopathological picture of the pancreas by induction of alloxan and extracts of the moon flower (tithonia diversifolia) in wistar rats (rattus norvegicus). A total of 24 male Wistar rats with 4 treatments were control P0, alloxan P1 with $1 \%$ CMC Na, P2 alloxan with 100mg / $\mathrm{kgBB}$ extract, alloxan P3 with 200mg / $\mathrm{kgBB}$ extract. Mice after said diabetes mellitus with a number $>135 \mathrm{mg} / \mathrm{dL}$ were then given treatment with $1 \% \mathrm{CMC} \mathrm{Na}$ on P1 and lunar leaf extract at $P 2$ and P3, necropsy was carried out on the 15th day and the pancreatic organs were taken to be made in the form of preparations with coloring. HE, lesions observed Degeneration, Inflammatory Cells and Necrosis using a microscope, the results were analyzed using Kruskal wallis followed by Mann withney. The data obtained by degeneration in the kruskal wallis test were very significantly different because there were significant differences $(P=0.01)$, inflammation cells in the Kruskal wallis test were very significantly different because there were significant differences $(P=0.00)$, and for necrosis in the Kruskal wallis test significantly different because there are significant differences (0.02).
\end{abstract}

Keywords : Alloxan, Extracts of the moon flower (Tithonia diversifolia), Pancreas Histopathology, Wistar rat.

\section{PENDAHULUAN}

Suatu gangguan karbohidrat, lipid dan protein dengan berbagai penyebab penyakit kronik yaitu Diabetes Mellitus (Wisudanti, 2016). Pada penderita diabetes mellitus terlihat gejala khasnya yaitu poliuria, polidipsi dan polifagia, yang disertai hasil pemeriksaan glukosa darah sewaktu lebih dari $200 \mathrm{mg} / \mathrm{dL}$ atau glukosa darah puasa lebih dari $126 \mathrm{mg} / \mathrm{dL}$. Kerusakan yang dapat disebabkan oleh infeksi virus, reaksi autoimun berupa serangan antibodi terhadap sel-sel $\beta$, zat diabetogenik (Stroptozotosin, Aloksan), toksisitas glukosa, kegemukan dan faktor genetik. Kerusakan yang disebabkan oleh virus, autoimun dan zat diabetogeneik dapat menyebabkan Diabetes Mellitus tipe 1 (Madihah dkk, 2016).

Hiperglikemia yang terjadi terus menerus mengindikasikan terjadinya Diabetes Mellitus. Sejalan dengan perkembangan zaman, pemberian pakan dan pola pemeliharaan juga berubah. Kucing diberi pakan siap saji, camilan dari pemilik seperti coklat, sehingga berpengaruh sebagai pemicu Diabetes Mellitus.
Kejadian Diabetes Mellitus pada kucing di Inggris dilaporkan sangat tinggi yaitu 1 ekor dari 200 ekor populasi kucing. Faktor pemicu diabetes mellitus pada kucing di Inggris dilaporkan karena terjadinya obesitas, kurangnya latihan (terutama pada kucing rumah), dan umur terutama pada kucing yang lebih tua (Fitriani dkk, 2016). Keadaan ini terjadi akibat ketidakseimbangan antioksidan dalam tubuh sedangkan tubuh tidak mempunyai sistem pertahanan antioksidatif yang berlebihan sehingga membutuhkan antioksidan eksogen sebagai penghambat kerusakan oksidatif dalam tubuh (Dewi, 2018).

Penggunaan obat-obat hipoglikemik dapat menyebabkan beberapa efek samping. Berbagai efek samping obat kimia sintetik yang memerlukan biaya yang relatif mahal menyebabkan pengobatan tradisional mendapat tempat dimasyarakat dan menjadi alternatif pengobatan. Salah satu tumbuhan yang memiliki potensi obat adalah tanaman kembang bulan (Tithonia diversifolia). Kembang bulan secara tradisional digunakan sebagai obat sakit perut, kembung, diare, dan anti radang atau antiinflamasi. Bagian tanaman kembang bulan 
yang dimanfaatkan sebagai sumber zat kimia adalah daun, akar, batang, buah, dan biji. Daun kembang bulan mengandung senyawa alkaloid, terpenoid, flavonoid, saponin, tanin, polifenol, dan golongan seskuiterpen. Pembuatan daun kembang bulan (Tithonia diversifolia) menjadi bentuk ekstrak dengan menggunakan pelarut etanol dikarenakan etanol dapat mengikat senyawa-senyawa kimia dalam daun yang bersifat polar misalnya flavonoid, flavonoid adalah senyawa polar karena mempunyai gugus hidroksil atau gula sehingga dapat larut dalam pelarut polar seperti etanol, metanol, aseton, dimetilsulfoksida dan air (Oktaria, 2013).

Sebagai salah satu kelenjar endokrin, pankreas bertanggung jawab dalam mengatur kadar glukosa darah. Perubahan kadar glukosa dalam plasma mengakibatkan penyesuaian sekresi insulin untuk mengembalikan kadar glukosa darah pada rentang yang normal. Insulin merupakan hormon anabolik utama yang meningkatkan cadangan energi (Erwin, 2013). Untuk mengetahui gambaran histopatologi yang terjadi pada organ pankreas tikus wistar setelah pemberian aloksan dan ekstrak daun kembang bulan (Tithonia diversifolia) belum diketahui secara pasti, oleh karena itu perlunya penelitian lebih lanjut untuk menjawab pertanyaan tersebut.

Tikus putih memiliki beberapa keuntungan sebagai hewan uji penelitian diantaranya perkembangbiakan cepat, mempunyai ukuran yang lebih besar dari mencit, mudah dipelihara dalam jumlah yang banyak. Ciri-ciri dari tikus putih (Rattus norvegicus) adalah seperti tikus pada umumnya, namun pada umumnya tikus putih (Rattus norvegicus) mempunyai warna albino, kepala kecil dan ekor yang lebih panjang dibandingkan badannya, pertumbuhannya cepat, temperamennya baik, kemampuan laktasi tinggi dan tahan terhadap arsenik tirosid (Akbar, 2010).

Aloksan digunakan untuk menginduksi diabetes pada hewan model diabetes seperti kelinci, tikus, mencit dan anjing. Pada hewan coba, aloksan menginduksi respon keseimbangan kadar glukosa dalam darah sehingga akan mempengaruhi konsentrasi plasma darah yang diikuti dengan perubahan struktur pada sel $\beta$ pankreas dan dapat menimbulkan kematian sel (Rohilla,dkk. 2012). Tingkat keparahan penyakit diabetes yang ditimbulkan aloksan bisa diatur dengan memvariasikkan dosis aloksan yang diberikan pada hewan coba (Etuk, 2010).

Tingginya konsentrasi aloksan tidak mempunyai pengaruh pada jaringan percobaan lainnya. Mekanisme aksinya menimbulkan perusakan selektif sel beta pankreas belum diketahui dengan jelas. Efek diabetogeniknya bersifat antagonis terhadap glutathion yang bereaksi dengan gugus $\mathrm{SH}$.

Daun kembang bulan ( $T$. diversifolia) mengandung flavonoid, glikosida, saponin, tanin dan steroid menurut hasil skrining fitokimia oleh Purba (2003). Menurut Taofik et al. (2010), ekstrak air daun kembang bulan mengandung flavonoid, alkaloid, dan tanin. Tanin memiliki aktivitas hipoglikemik dengan meningkatkan glikogenesis (Dalimartha, 2005). Saponin mempu menghambat GLUT-1 sehingga menurunkan absorbsi glukosa (Blasiak et al., 2003). Flavonoid sebagai antioksidan dapat melindungi kerusakan progresif sel $\beta$ pankreas karena stress oksidatif sehingga dapat menurunkan DM tipe 2 (Song et al., 2005).

Diabetes Mellitus (DM) adalah suatu kelompok penyakit metabolik dengan karakteristik hiperglikemia yang terjadi karena kelainan sekresi insulin, gangguan kerja insulin, atau keduanya yang menimbulkan berbagai komplikasi kronik pada mata, ginjal, syaraf dan pembuluh darah (PERKENI, 2011). Menurut American Diabetes Association (2015), DM merupakan suatu penyakit kronis komplek yang membutuhkan perawatan medis yang lama atau terus menerus dengan cara mengendalikan kadar gula darah untuk mengurangi resiko multifaktoral.

Pankreas tikus terletak di samping duodenum, memanjang dari lambung menuju limpa (Dolensek, J., dkk. 2015). Pankreas merupakan organ tubuh yang istimewa yang memiliki fungsi ganda sebagai kelenjar eksokrin dan endokrin.

\section{MATERI DAN METODE}

Penelitian dilaksanakan di Laboratorium Hewan Coba FK Unair, Laboratorium Farmakologi FKH Universitas Airlangga, Laboratorium Patologi Anatomi Fakultas Kedokteran UGM dan Laboratorium Patologi FKH Universitas Wijaya Kusuma Surabaya. 
Penelitian ini berlangsung dari bulan Maret-April 2020.

Penelitian ini adalah true experimental laboratories dengan Rancangan Acak Lengkap (RAL) dengan teknik pengambilan sampel dilakukan secara random/ acak dengan 4 perlakuan. Daun Kembang Bulan (Tithonia diversifolia) yang akan di ekstrakkan sebanyak $500 \mathrm{~g}$ dalam keadaan kering. Kemudian digiling untuk menjadi dalam bentuk serbuk. Serbuk tersebut di maserasi dengan menggunakan larutan etanol 96\%. Penambahan larutan maserasi dilakukan berkali-kali sampai terlihat larutan bening. Larutan hasil maserasi disaring menggunakan kapas dan kertas saring, kemudian filtrate yang diperoleh, dikumpulkan dan dikentalkan dengan menggunakan alat penguap berputar (rotary evaporator) yang dilengkapi penangas air dan pompa vakum dengan temperatur penangas $60^{\circ} \mathrm{C}$ sampai bebas etanol. Ekstrak daun kembang bulan yang diperoleh diencerkan dengan $\mathrm{CMCNa} 1 \%$ setelah itu diberikan pada tikus sesuai dengan perlakuan. Proses maserasi dilakukan di Laboratorium Farmakologi FKH Unair.

Pemberian ekstrak daun kembang bulan (Tithonia diversifolia) pada tikus wistar secara peroral selama tujuh hari. Langkah yang dilakukan pertama di mulai dengan pengambilan ekstrak dengan sonde yang ujungnya terbuat dari karet, untuk mengencerkan ekstrak Daun Kembang Bulan (Tithonia diversifolia) dengan menggunakan larutan CMC Na $1 \%$.

Aloksan terbukti dapat menimbulkan diabetes melitus dengan cara merusak sel $\beta$ pankreas sehingga pankreas tidak dapat menghasilkan insulin yang cukup. Dosis Aloksan yang diberikan setiap tikus percobaan dari P1, P2 dan P3 diberikan dosis 100 $\mathrm{mg} / \mathrm{kgBB}$. Pembuatan aloksan dengan ditambahkan aquadest injeksi karena nantinya zat diabetogenik tersebut akan disuntikkan secara intraperitoneal. Berat tikus yang digunakan dalam penelitian adalah $150 \mathrm{~g}$ sampai $200 \mathrm{~g}$, dibawah ini contoh perhitungan dosis aloksan, jika berat tikus 200g maka dosis perekor tikus sebesar $200 \mathrm{~g}=0,2 \mathrm{~kg}$, maka 100 $\mathrm{mg} / \mathrm{kgBB}$ X $0,2 \mathrm{~kg}=20 \mathrm{mg}$ (perekor tikus) pada P1, P2 dan P3 di berikan aloksan selama tiga hari secara intraperitoneal dan diberikan ekstrak daun kembang bulan secara per oral.
Tikus berumur dua sampai tiga bulan dan berat badan 150-200 gram sebanyak 24 ekor, yang dikelompokkan dalam 4 kelompok yang dilakukan selama empat belas hari. Macam perlakuan sebagai berikut:

$\mathrm{P} 0=$ Diberikan aquades setiap hari secara per oral (kontrol).

$\mathrm{P} 1=$ Diberikan aloksan $100 \mathrm{mg} / \mathrm{kgBB}$ per tikus secara peritoneal pada hari ke 1 sampai hari ke 7. Kemudian dihari ke 8-14 diberikan suspensi CMC Na $1 \%$.

P2= Diberikan aloksan $100 \mathrm{mg} / \mathrm{kgBB}$ per tikus secara peritoneal pada hari ke 1 sampai hari ke 7. Kemudian di hari ke 8 sampai hari ke 14 di berikan ekstrak daun kembang bulan dengan dosis $100 \mathrm{mg} / \mathrm{kg} \mathrm{BB}$.

P3= Diberikan aloksan $100 \mathrm{mg} / \mathrm{kgBB}$ per tikus secara peritoneal pada hari ke 1 sampai hari ke 7. Kemudian di hari ke 8 sampai hari ke 14 di berikan ekstrak daun kembang bulan dengan dosis $200 \mathrm{mg} / \mathrm{kg} \mathrm{BB}$.

Pada pemberian aloksan hanya di lakukan pada hari ke 1 setelah itu di tes gulanya menggunakan alat cek gula darah atau disebut blood glucose meter. Berdasarkan Wolfenshon and Lloyd, (2013) kadar gula darah normal 50$135 \mathrm{mg} / \mathrm{dL}$ dan dikatakan terkena diabetes lebih dari $150 \mathrm{mg} / \mathrm{dL}$. Terdapat juga menurut Oktaria, (2013) tikus atau hewan lain dikatakan diabetes dengan kadar gula darah lebih dari 200 $\mathrm{mg} / \mathrm{dL}$.

Empat belas hari setelah perlakuan, dilakukan pembedahan secara laparatomi pada tikus yang telah dinekropsi dan dieutanasi dengan ether secara inhalasi dengan cara setiap interval 5 menit suntikan $0,2 \mathrm{ml}$ eter kedalam kapas kemudian masukkan kapas tersebut kedalam aquarium kecil yang tertutup dan tikus dimasukkan kedalamnya dan lakukan setiap 5 menit sampai semua tikus mati (Yanti dkk, 2015). Mengambil organ pankreasnya. Organ yang diperoleh kemudian difiksasi kedalam Buffer Neutral Formalin (BNF) 10\% sebelum akhirnya dibuat preparat histopatologi dengan pewarnaan Hematoxyline Eosin (HE) untuk pemeriksaan secara mikroskopik.

Metode skoring yang diamati dalam perubaan histopatologi dilihat dari derajat kerusakan pada jumlah dari semua jenis lesi yang terjadi, kerusakan tersebut di berikan skor dari 0 hingga 10. Data tersebut diperoleh dari gambaran histopatologi yang dianalisis dengan 
mikroskop cahaya oleh ahli patologi (Solfaine, 2019).

Lesi- lesi yang diamati berdasarkan parameter yang akan di teliti antara lain yaitu:

\section{Degenerasi}

Dikategorikan dalam lima skala antara lain yaitu :

a) Skor 0 : jika tidak ditemukan perubahan degeneratif

b) Skor 1: jika jumlah sel degeneratif dengan derajat kerusakan $(<1-25 \%)$ dari seluruh LP (Lapang Pandang).

c) Skor 2: jika jumlah sel degeneratif dengan derajat kerusakan (26-50\%) dari seluruh LP ( Lapang Pandang).

d) Skor 3: jika jumlah sel dengan derajat kerusakan $(51 \%-75 \%)$ dari seluruh LP (Lapang Pandang).

e) Skor 4: jika jumlah sel degeneratif > 76 dari seluruh LP

\section{Nekrosis}

Dikategorikan dalam 5 skala antara lain yaitu :

a) Skor 0 : tidak terjadi perubahan nekrotik

b) Skor 2 : jika jumlah sel nekrotik $<25 \%$ dari seluruh LP.

c) Skor 4 : jika jumlah sel nekrotik antara 26\%-50\% dari seluruh LP.

d) Skor 6 : jika jumlah sel nekrotik antara $51 \%-75 \%$ dari seluruh LP.

e) Skor $8:$ jika jumlah sel nekrotik $76 \%$ dari seluruh LP.

\section{Sel Radang}

Dikategoriakan dalam 5 skala antara lain yaitu :

a) Skor 0 : jika tidak ditemukan sel radang pada seluruh ruang interstitial pankreas.

b) Skor 1 : jika jumlah sel radang < 10 pada seluruh ruang interstitial pankreas.

c) Skor 2 : jika jumlah sel radang antara 11-50 pada seluruh ruang interstitial pankreas.

d) Skor 3: jika jumlah sel radang antara 51-100 pada seluruh ruang interstitial pankreas.

e) Skor 4: jika jumlah sel radang > 100 pada seluruh ruang interstitial pankreas.
HASIL

Berdasarkan hasil penapisan fitokimia ekstrak daun kembang bulan (Tithonia diversfolia) kandungan flavonoid, saponin, tanin, sesquerterpen dapat di lihat di tabel 1

Tabel 1. Hasil analisis kandungan senyawa flavonoid, saponin, tanin dan sesquerterpen data dianalisis secara kuantitatif.

\begin{tabular}{lc}
\hline Senyawa & $\begin{array}{c}\text { Kandun } \\
\text { gan \% }\end{array}$ \\
\hline Flavonoid & $2,86 \%$ \\
\hline Saponin & $2,10 \%$ \\
\hline Tanin & $4,03 \%$ \\
\hline Sesquerte & $1,98 \%$ \\
\hline
\end{tabular}

Tabel 2. Kadar Gula Darah Saat Diinduksi Aloksan.

\begin{tabular}{|c|c|c|}
\hline $\begin{array}{c}\text { Perlakua } \\
\text { n }\end{array}$ & $\begin{array}{c}\text { Rata-rata } \\
\pm \text { Std. } \\
\text { Deviation }\end{array}$ & $\begin{array}{c}\text { Rata- } \\
\text { rata } \pm \text { Std. } \\
\text { Deviation }\end{array}$ \\
\hline P0 & $111.1 \pm 17.371$ & $\begin{array}{l}85.64 \pm 20.47 \\
1\end{array}$ \\
\hline P1 & $\begin{array}{c}328.8 \pm 144.46 \\
5 \\
\end{array}$ & $\begin{array}{c}150.1 \pm 49.42 \\
2 \\
\end{array}$ \\
\hline $\mathbf{P 2}$ & $\begin{array}{c}240.5 \pm 159.42 \\
5\end{array}$ & $87.17 \pm 8.819$ \\
\hline P3 & $\begin{array}{c}313.6 \pm 164.01 \\
8\end{array}$ & $82.33 \pm 7.967$ \\
\hline Total & $\begin{array}{l}248.5 \pm 153.96 \\
2\end{array}$ & $\begin{array}{c}101.3 \pm 38.54 \\
2 \\
\end{array}$ \\
\hline
\end{tabular}

Tabel 3 Persentase (\%) hasil skoring pemeriksaan histopatologi kelompok kontrol, perlakuan I, perlakuan II, perlakuan III.

\begin{tabular}{llll}
\hline Kelompok & Degenerasi & $\begin{array}{l}\text { Sel } \\
\text { Radang }\end{array}$ & Nekrosis \\
\hline P0 & $0 \%$ & $100 \%$ & $100 \%$ \\
\hline P1 & $100 \%$ & $100 \%$ & $100 \%$ \\
\hline P2 & $100 \%$ & $100 \%$ & $100 \%$ \\
\hline P3 & $100 \%$ & $82.5 \%$ & $100 \%$ \\
\hline
\end{tabular}

Data skoring diatas telah didapatkan, kemudian akan dibuat diagram batang untuk diamati tiap derajat kerusakan agar mempermudah dalam menganalisis tiap perubahan lesi yang terjadi. 


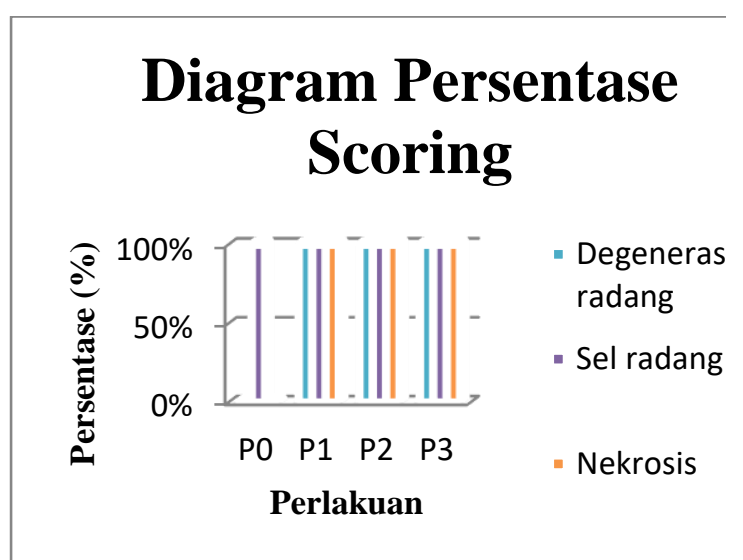

Gambar 1. Diagram persentase Scoring Organ Pank reas Setelah dilakukan perlakuan kontrol, P1, P2 dan P3.

Tabel 4 Uji Kruskal Wallis, degenerasi.

\begin{tabular}{|c|c|c|}
\hline Perlakuan & $\begin{array}{l}\text { Mean } \\
\text { Deviasi }\end{array}$ & \pm Standar \\
\hline P0 & .00 & $\pm .000^{\mathrm{a}}$ \\
\hline P1 & 4.00 & $\pm .000^{\mathrm{b}}$ \\
\hline P2 & 3.33 & $\pm .816^{\mathrm{b}}$ \\
\hline $\mathbf{P 3}$ & 3.17 & $\pm .753^{\mathrm{c}}$ \\
\hline Total & 2.63 & \pm 1.6633 \\
\hline
\end{tabular}

Keterangan :

Apabila nilai Sig $\mathrm{P}>0.05$, maka tidak ada perbedaan antar perlakuan. Apabila nilai sig. $<0.05$, maka terdapat berbedaan yang signifikan pada ratarata peradangan antar kelompok kontrol dengan perlakuan. Berdasarkan pengujian yang dilakukan pada uji untuk degenerasi nilai Sig 0,001 maka $(\mathrm{P}<0,001)$ maka terdapat perbedaan yang sangat signifikan antar perlakuan, atau dapat di simpulkan jika P0 kontrol dengan Perlakuan ada perbedaan, P0 dengan P1 berbeda, P1 dengan P2 tidak berbeda, P2 dengan P3 berbeda. Sehingga H0 di tolak dan H1 diterima. Untuk mengetahui perbedaan yang lebih signifikan dilanjutkan dengan uji Mann- Whitney.

Tabel 5. Uji Krustal Wallis, Sel radang

\begin{tabular}{crl}
\hline Perlakuan & $\begin{array}{c}\text { Mean } \\
\text { Deviasi }\end{array}$ & $\mathbf{\pm}$ Standar \\
\hline P0 & 1.33 & $\pm .516^{\mathrm{a}}$ \\
\hline P1 & 4.00 & $\pm .000^{\mathrm{b}}$ \\
\hline P2 & 4.00 & $\pm .000^{\mathrm{b}}$ \\
\hline P3 & 3.33 & $\pm .516^{\mathrm{b}}$ \\
\hline Total & $\mathbf{3 . 1 7}$ & $\mathbf{\pm 1 . 1 6 7}$ \\
\hline
\end{tabular}

Kerterangan:
Apabila nilai Sig $\mathrm{P}>0.05$, maka tidak ada perbedaan antar perlakuan. Apabila nilai sig. $\mathrm{P}<0.05$, maka terdapat berbedaan yang signifikan pada rata-rata peradangan antar perlakuan kontrol dan perlakuan. Berdasarkan pengujian yang dilakukan pada uji untuk sel radang nilai Sig 0,000 maka $(\mathrm{P}<0,001)$ maka terdapat perbedaan yang sangat signifikan antar perlakuan. Atau daat disimpulkan P0 kontrol dengan $\mathrm{P}$ perlakuan berbeda, tetapi antar perlakuan tidak berbeda.. Sehingga HO di tolak dan $\mathrm{H} 1$ diterima. Untuk mengetahui perbedaan yang lebih signifikan dilanjutkan dengan uji Mann- Whitney.

Tabel 6. Uji Krustal Wallis, Nekrosis

\begin{tabular}{ccl}
\hline Perlakuan & $\begin{array}{c}\text { Mean } \\
\text { Deviasi }\end{array}$ & $\mathbf{\pm \text { Standar }}$ \\
\hline P0 & .00 & $\pm .000^{\mathrm{a}}$ \\
\hline P1 & 7.33 & $\pm 1.033^{\mathrm{b}}$ \\
\hline P2 & 7.00 & $\pm .1 .095^{\mathrm{b}}$ \\
\hline P3 & 6.67 & $\pm .1 .033^{\mathrm{b}}$ \\
\hline Total & $\mathbf{5 . 2 5}$ & $\mathbf{\pm 3 . 2 2 0}$ \\
\hline
\end{tabular}

Keterangan:

Apabila nilai Sig $\mathrm{P}>0.05$, maka tidak ada perbedaan antar perlakuan. Apabila nilai sig. $\mathrm{P}<0,05$, maka terdapat berbedaan yang signifikan antar perlakuan. Berdasarkan pengujian yang dilakukan pada uji untuk nekrosis nilai Sig 0,002 maka $(\mathrm{P}<0,05)$ maka terdapat perbedaan yang signifikan apada ratarata peradangan antar kelompok kontrol dan kelompok perlakuan, atau dapat disimpulkan P0 dengan antar perlakuan berbeda tetapi antar perlakuan tidak berbeda. Sehingga H0 di tolak dan $\mathrm{H} 1$ diterima. Untuk mengetahui perbedaan yang lebih signifikan dilanjutkan dengan uji Mann- Whitney.

\section{Gambaran Histopatologi Pankreas}

Berikut adalah gambaran histopatologi pankreas tikus wistar (rattus norvegicus) percobaan yang diinduksi aloksan dan ekstrak daun kembang bulan (Tithonia diversifolia) dengan pewarnaan HE (Haematoxylin Eosin) pada kelompok perlakuan P0, P1, P2, P3. 


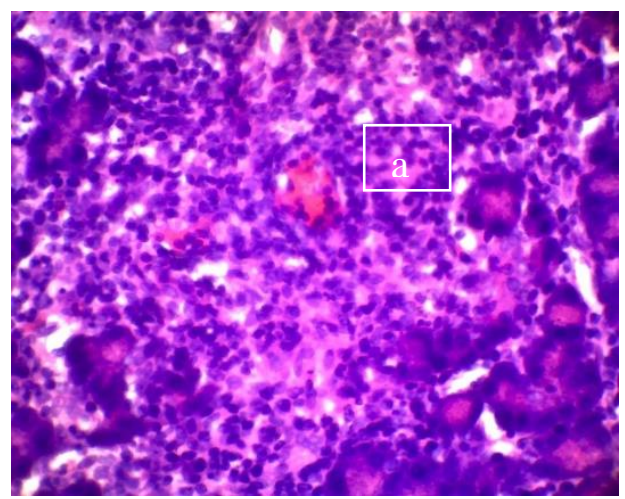

Gambar 1. Gambaran Histopatologi pankreas pada kelompok kontrol yang menunjukkan (a) pulau langerhans normal (Haematoxylin Eosin: 40X).

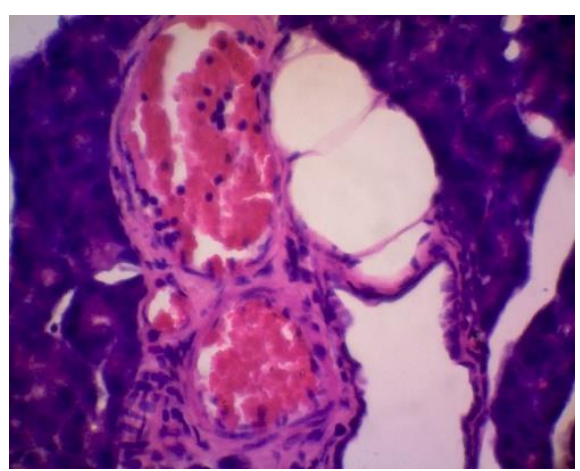

Gambar 2 Gambaran histopatologi pankreas pada kelompok kontrol (P0) yang menunjukkan (b) sel parenkim normal (Haematoxylin eosin:40X).

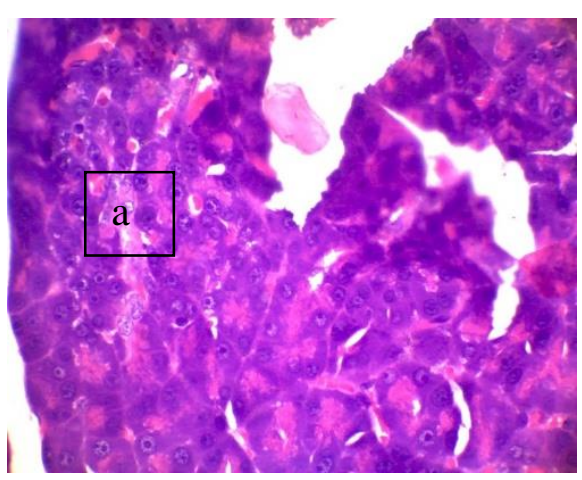

Gambar 3. Gambaran histopatologi pankreas pada kelompok perlakuan (P2) yang menunjukkan (a) degenerasi. (Haematoxylin eosin: 40X).

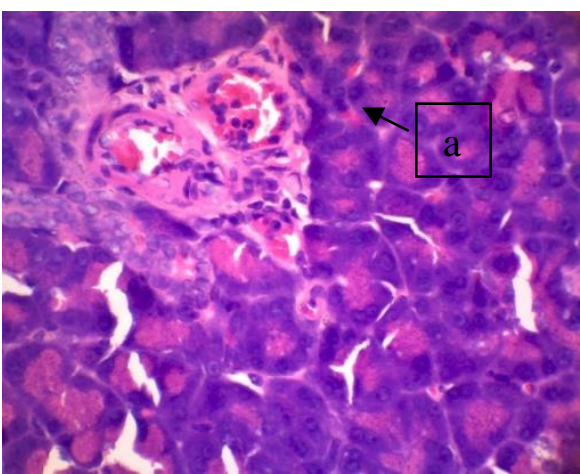

Gambar 4. Gambaran histopatologi pankreas pada kelompok perlakuan (P1) yang menunjukkan (a) sel radang. (Haematoxylin eosin: 40X).

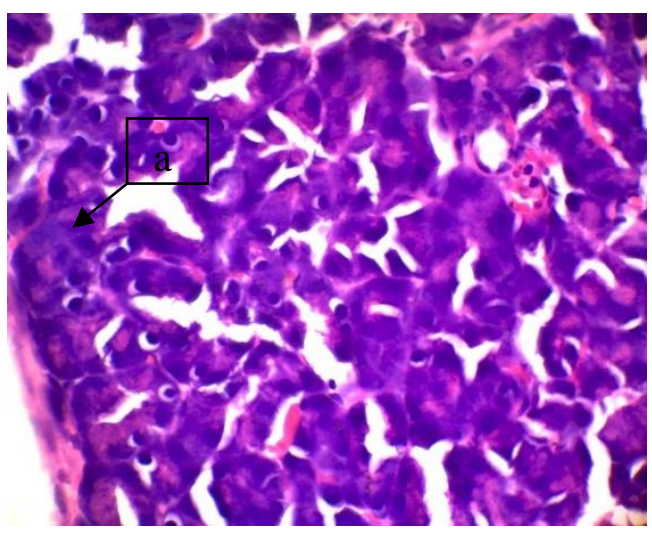

Gambar 4. Gambaran histopatologi pankreas pada kelompok perlakuan (P2) yang menunjukkan (a) piknosis (b) sel yang mengalami regenerasi.

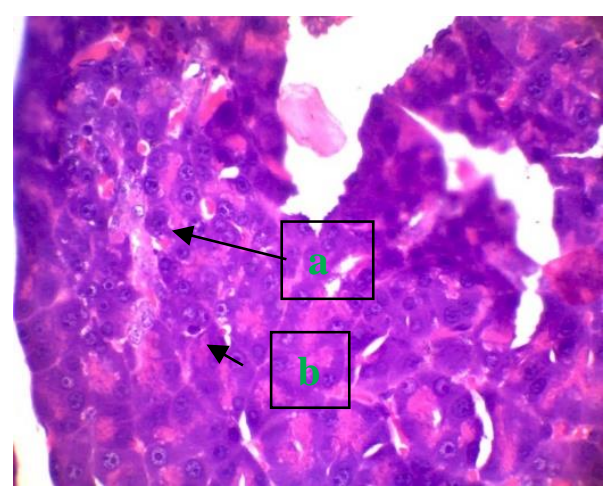

Gambar 5 Gambaran histopatologi pankreas pada kelompok perlakuan (P2) yang menunjukkan (b) karioreksis (c) kariolisis. 


\section{PEMBAHASAN}

Ekstraksi Daun Kembang Bulan (Tithonia diversifolia) Pada tabel 4.1 di data hasil terdapat besar persen senyawa flavonoid, saponin, tanin dan sesquerterpen. Menurut Chon et al (2000) yang memiliki peran antidiabetik atau antihiperglikemik pada kandungan ekstrak daun kembang bulan (Tithonia diversifolia) yaitu flavonoid dan suskuiterpen. Dimana dari hasil analisis fitokimia secara kuantitatif di dapatkan senyawa flavonoid memiliki nilai $2.86 \%$ dan suskuiterpen memiliki nilai $1.98 \%$ dimana nilai itu adalah nilai yang cukup besar, untuk mengatasi diabetes melitus. Fungsi dari flavonoid sendiri diketahui berperan secara signifikan meningkatkan aktifitas enzim antioksidan dan mampu meregenerasi sel-sel $\beta$ pankreas yang rusak sehingga defisiensi insulin dapat diatasi. Flavonoid yang terkandung di dalam tumbuhan diduga juga dapat memperbaiki daya kerja reseptor insulin, sehingga memberikan efek yang menguntungkan pada keadaan diabetes mellitus (Eryuda, dkk., 2016).

Fungsi seskuiterpen yang diisolasi dari ekstrak daun kembang bulan (Tithonia diversifolia) memiliki daya sebagai agen fitoterapik melawan infeksi bakteri pada organ (Pradeep et al., 2010). Seskuiterpen yang diisolasi dari tanaman menunjukkan aktivitas penghambat $\alpha$-glukosidase yang signifikan (Choudhary, 2001). Seskuiterpen juga bisa menghambat ekspresi induksi glukosa tinggi pada inflamasi sitokinin pada sel mesangial.

Pada tabel 1 juga diketahui nilai senyawa dari tanin dan saponin, dimana nilai $\operatorname{tanin} 4.03 \%$ dan saponin $2.10 \%$. fungsi tanin sebagai penghambat $\alpha$-glukosidase yang bermanfaat untuk menunda absorpsi glukosa setelah makan sehingga menghambat kondisi hiperglikemia postprandial. Enzim $\alpha$ glukosidase meliputi maltese, isomaltase, sukrase, laktase, dan $\alpha$-dekstrinase. Karbohidrat akan dicerna oleh enzim didalam mulut dan usus menjadi gula yang lebih sederhana yang kemudian akan diserap kedalam tubuh dan meningkatkan kadar gula darah (Eryuda, 2016).

Saponin sendiri memiliki kecenderungan melepaskan insulin dari sel $\beta$ pankreas dan memiliki kemampuan untuk melindungi sel $\beta$ pankreas dan membuat besarnya degranulasi dari insulin berkurang sedikit dari yang sebelumnya dan saponin secara signifikan memperbaiki gejala klinik dari diabetes termasuk kadar glukosa darah yang tinggi dan menyerupai mekanisme kerja penghambat enzim $\alpha$-glukosidase (Anwar, 2016).

\section{Kosentrasi Gula Darah}

Kadar gula darah normal tikus menurut Wolfenshon dan Lloyd, (2013) kadar gula darah normal 50-135mg/dL dan dikatakan terkena diabetes mellitus lebih dari $150 \mathrm{mg} / \mathrm{dL}$. Pada tikus uji rerata kadar gula darah pada tikus uji setelah diberikan perlakuan aloksan $100 \mathrm{mg} / \mathrm{kgBB}$ P1 (328.8), P2 (240.5), P3 (313.6) pada pemberian zat diabetogenik aloksan menunjukkan kadar gula darah tikus meningkat melebihi $135 \mathrm{mg} / \mathrm{dL}$ sehingga dapat dikatakan tikus uji mengalami diabetes mellitus sedangkan untuk perlakuan setelah diberikan ekstrak mengalami penurunan sehingga P1 $(158,6)$, P2 $(87,7)$, P3 $(82,3)$ pada pemberian ekstrak mengalami penurunan gula darah hingga dibawah $135 \mathrm{mg} / \mathrm{dL}$.

\section{Penilaian hasil histopatologi pankreas pada tikus hewan coba pada perlakuan P0,P1, P2, P3. \\ Pada tabel 2 adalah rerata scoring pemeriksaan histopatologi pankreas tikus uji yang mana diamati lesi - lesinya yaitu degenerasi, sel radang dan nekrosis.}

\section{Degenerasi}

Lesi degenerasi pada perlakuan P0 tidak di temukan tetapi di perlakuan P1,P2, dan P3 ditemukan degenerasi setelah diberikan perlakuan dengan aloksan dan daun kembang bulan (Tithonia diversifolia) untuk scor tertinggi perlakuan yang mengalami degenerasi adalah P1 dengan bobot scor 4 dengan nilai presentase $(100 \%)$ dimana $\mathrm{P} 1$ adalah perlakuan yang diberikan aloksan $100 \mathrm{mg} / \mathrm{kgBB}$ selama 7 hari dan CMC Na 1\% selama 7 hari setelah dikatakan tikus mengalami diabetes mellitus, untuk P2 yang mengalami degenerasi rerata nilai scornya 3.3 dengan nilai presentase $(100 \%)$ dan masih terdapat sel normal yang 
ditemukan, dimana P2 ini adalah perlakuan yang diberikan aloksan $100 \mathrm{mg} / \mathrm{kgBB}$ dan Ekstrak daun kembang bulan $100 \mathrm{mg} / \mathrm{kgBB}$ setelah dikatakan hewan uji mengalami diabetes mellitus, kemudian P3 memiliki bobot scor terendah yaitu 3.1 dengan nilai presentase (100\%) dimana P3 adalah perlakuan yang diberikan aloksan $100 \mathrm{mg} / \mathrm{kgBB}$ dan Ekstrak daun kembang bulan $200 \mathrm{mg} / \mathrm{kgBB}$. Sehingga dapat disimpulkan untuk degenerasi yang paling efektif adalah pemberian ekstrak daun kembang bulan $200 \mathrm{mg} / \mathrm{kgBB}$.

Pengamatan terhadap histopatologi pankreas difokuskan pada kejadian degenerasi, sel radang dan nekrosis. Pengamatan pada kelompok kontrol tidak ditemukan degenerasi dan nekrosis, sedangkan sel radang ditemukan sedikit. Kejadian yang parah di tujukan pada perlakuan P1 dengan diberikan aloksan $100 \mathrm{mg} / \mathrm{kgBB}$ dengan CMC Na $1 \%$. Degenerasi sendiri adalah degenerasi hidropik ditandai dengan sitoplama mengalami vakuolisasi dan vakuola nampak jernih karena sel menerima cairan lebih banyak dari normalnya dan terakumulasi di dalam sitoplasma sel sehingga sel membengkak, sedangkan degenerasi lemak adalah sebagai tanda keadaan resistensi insulin dan mengakibatkan terjadinya inflamasi melalui aktivasi beberapa sitokin (Istikhomah dan Lisdiana, 2015).

\section{Sel Radang}

Lesi Sel radang yang paling sedikit di temukan adalah pada perlakuan P0 dengan bobot scor rerata 1.1 yang hanya diberikan aquades dan makan, P1 dan P2 ditemukan banyak sel radang dan bobot scor paling tinggi di pembuluh darah khususnya dimana P1 dengan scor 4 dan presentase $(100 \%)$ adalah perlakuan yang diberikan Aloksan $100 \mathrm{mg} / \mathrm{kgBB}$ dan CMC Na $1 \%$ dan P2 dengan scor 4 dan presentase (100\%) adalah perlakuan yang diberikan aloksan $100 \mathrm{mg} / \mathrm{kgBB}$ dan ekstrak daun kembang bulan $100 \mathrm{mg} / \mathrm{kgBB}$ sedangkan pada P3 dengan scor sel radang yang di temukan memiliki bobot scor 3.3, dimana P3 adalah perlakuan yang diberikan aloksan $100 \mathrm{mg} / \mathrm{kgBB}$ dan ekstrak daun kembang bulan $200 \mathrm{mg} / \mathrm{kgBB}$.

\section{Nekrosis}

Lesi Nekrosis pada perlakuan P0 tidak ditemukan adanya inti sel mengalami (piknosis, karioreksis dan kariolisis) dimana hanya diberikan aquades tanpa perlakuan. P1 menunjukkan scor yang paling tinggi yang diberikan perlakuan aloksan $100 \mathrm{mg} / \mathrm{kgBB}$ dan CMC Na1\% dengan scor 7.3 dengan presentase (100\%), kemudian untuk P2 juga terdapat jumlah nekrosis yang tinggi yang scornya 7 dengan presentase $(100 \%)$ dimana diberikan perlakuan aloksan $100 \mathrm{mg} / \mathrm{kgBB}$ dan ekstrak daun kembang bulan $200 \mathrm{mg} / \mathrm{kgBB}$, kemudian untuk P3 adalah scor paling rendah yaitu 6.6 dengan presentase $(100 \%)$ dengan pemberian aloksan $100 \mathrm{mg} / \mathrm{kgBB}$ dan ekstrak daun kembang bulan $200 \mathrm{mg} / \mathrm{kgBB}$. Nekrosis adalah kematian sel atau jaringan dimana inti sel mengalami korioreksis, kariolisis, inti sel lebih padat atau piknosis (Palupi, 2012). Penurunan pada kelompok P3 dengan pemberian ekstrak dosis $200 \mathrm{mg} / \mathrm{kgBB}$.

Setelah pengobatan dengan ekstrak daun kembang bulan ditemukan degenerasi, sel radang dan nekrosis berkurang secara signifikan $(\mathrm{P}<0.05)$ terutama pada kelompok dosis $200 \mathrm{mg} / \mathrm{kgBB}$ dan $100 \mathrm{mg} / \mathrm{kgBB}$ adanya sel asinar pankreas yang tersebar di beberapa bagian jaringan pankreas yang menandakan terjadinya proses pembentukan baru sel $\beta$ pankreas. Pankreas tikus diabetes mellitus yang diinduksi aloksan memperlihatkan adanya degenerasi, sel radang daan nekrosis terutama pada kelenjar eksokrin, pulau langerhans, dan disekitar pembuluh darah, sedangkan pada kelompok pengobatan dengan ekstrak daun kembang bulan kejadian tersebut lebih sedikit.

Perbaikan kerusakan pankreas diduga disebabkan oleh aktivitas senyawa aktif dalam ekstrak daun kembang bulan (Tithonia diversifolia) yaitu flavonoid, siskuiterpen, alkaloid, saponin dan tanin. Adanya aktivias antiinflamasi senyawa flavonoid serta aktivitas antioksidan dapat mencegah kerusakan sel $\beta$ lebih lanjut. Alkaloid di dalam ekstrak daun kembang bulan berperan meregenerasi sel dengan memulihkan sel $\beta$ pankreas yang mengalami kerusakan parsial (Palupi, 2012). Pulihnya sel beta pankreas diharapkan akan memulihkan fungsinya dalam memproduksi hormon insulin. Peningkatan jumlah insulin di dalam tubuh akan meningkatkan jumlah glukosa darah yang masuk kedalam sel, 
sehingga terjadi penurunan kadar glukosa darah.

\section{KESIMPULAN}

Berdasarkan hasil penelitian dan pembahasan yang disampaikan dapat disimpulkan bahwa:

1. Pemberian induksi aloksan melalui i.p $100 \mathrm{mg} / \mathrm{kgBB}$ dan ekstrak daun kembang bulan (Tithonia diversifolia) $100 \mathrm{mg} / \mathrm{kgBB}$ dan $200 \mathrm{mg} / \mathrm{kgBB}$ memiliki pengaruh terhadap gambaran histopatologi degenerasi sel pankreas tikus putih (Rattus norvegicus) dengan pewarnaan HE. Pemberian ekstrak daun kembang bulan mampu menurunkan jumlah kerusakan degenerasi dan signifikasi atau berbeda nyata pada setiap perlakuan dengan uji kruskal wallis P0 dengan semua perlakuan berbeda, P1 dengan P2 tidak berbeda, sedangkan $\mathrm{P} 2$ dengan $\mathrm{P} 3$ berbeda.

2. Pemberian induksi aloksan melalui i.p $100 \mathrm{mg} / \mathrm{kgBB}$ dan ekstrak daun kembang bulan (Tithonia diversifolia) $100 \mathrm{mg} / \mathrm{kgBB}$ dan $200 \mathrm{mg} / \mathrm{kgBB}$ memiliki pengaruh terhadap gambaran histopatologi sel radang pankreas tikus putih (rattus norvegicus) dengan pewarnaan HE. Pemberian ekstrak daun kembang bulan mampu menurunkan jumlah sel radang pada pankreas dan signifikan atau berbeda nyata pada setiap perlakuan dengan uji kruskal wallis P0 dengan semua perlakuan berbeda tetapi antar perlakuan tidak berbeda.

3. Pemberian induksi aloksan melalui i.p $100 \mathrm{mg} / \mathrm{kgBB}$ dan ekstrak daun kembang bulan ( Tithonia diversifolia) $100 \mathrm{mg} / \mathrm{kgBB}$ dan $200 \mathrm{mg} / \mathrm{kgBB}$ memiliki pengaruh terhadap gambaran histopatologi nekrosis sel pankreas tikus putih (Rattus norvegicus) dengan pewarnaan HE. Pemberian ekstrak daun kembang bulan mampu menurunkan jumlah kerusakan nekrosis dan signifikan atau berbeda nyata pada setiap perlakuan dengan uji kruskal wallis P0 dengan antar perlakuan berbeda, tetapi antar perlakuan tidak berbeda.

\section{REFERENSI}

Dewi, K. E. D. P., W. J. Abdul., F. Rell., 2018. Uji Aktivitas Pisang Mas (Musa Acuminata (AA Group) Terhadap Penurunan Kadar Glukosa Darah Mencit (Mus Musculus) Yang Di
Induksi Aloksan. As-Syifaa. 10(2): 191-205.

Eryuda, F., T.U. Soleha., 2016. Ekstrak Daun Kluwih (Arthocarpus Camansi) dalam Menurunkan Kadar Glukosa Darah Yang Pada Penderita Diabetes Mellitus. Majoriti. Lampung. 5(4).

Erwin, E., W.M.I. Tri., 2013. Ekspresi Insulin Pada Pankreas Mencit (Mus musculus) Di Induksi Dengan Streptozotocin Berulang. Jurnal Kedokteran Hewan. Yogyakarta. $7(2)$.

Eryuda, F., T.U. Soleha., 2016. Ekstrak Daun Kluwih (Arthocarpus Camansi) dalam Menurunkan Kadar Glukosa Darah Yang Pada Penderita Diabetes Mellitus. Majoriti. Lampung. 5(4).

Etuk, E.U. 2010. Animal Model for Studyting Diabetes Mellitus. Agriculture and Biology Journal of

Istikhomah dan Lisdiana. 2015. Efek Hepatoprotektor Ekstrak Buah Pedada (Sonneratia Caseolaris) Pada Tikus Putih (Rattus norvegicus). Unnes Jurnal of Life Science. Semarang. 1: 1-8.

Fitriani, A., I. N. Suartha., Widyastuti, S.K., 2016. Kasus Diabetes Mellitus Pada Kucing Lokal. Indonesia Medicus Veternus. Bali. 5(5): 407-414.

Madihah., F. Alfina., Y.Y. Gani., 2016. Kadar Glukosa Darah Dan Gambaran Histologis Pankreas Mencit (Mus Musculus L.) Yang Diinduksi Aloksan Setelah Perlakuan Ekstrak Rimpang Temu Mangga (Curcuma Mangga Val.). Jurnal Biologi. 20(2): 64-68.

Oktaria, Y.E., 2013. Uji Aktivitas Antidiabetes Ekstrak Etanol Biji Alpukat (Persea Americana Mill) Terhadap Tikus Galur Wistar Yang Diinduksi Aloksan. [Makalah]. Surakarta: Fakultas Farmasi Universitas Muhammadiyah Surakarta. 
Palupi, D.H.S., 2012. Pengaruh Fraksi Etil Asetat Buah Labu Siam (Sechium Edule (Sacq.)Sw) Terhadap Regenerasi Sel B Pankreas Pada Tikus Diabetes Yang Diinduksi Aloksan. Sekolah Tinggi Ilmu Farmasi Yayasan Pharmasi. Semarang

Perkeni. 2011. Konsensus Pengelolaan Dan Pencegahan Diabetes Mellitus Tipe 2 Di Indonesia 2011. PB Perkeni. Jakarta.

Rohilla, A., and Ali, S. 2012. Alloxan Induced Diabetes: Mechanism and Effect. International Journal Of Research In Pharmaceutical And Biomedical Science. 3(2).

Solfaine, R., 2011. Patologi Veteriner Patogenesis Dasar Penyakit Hewan. Proyeksi Indonesia. Sleman.

Solfaine, R., 2019. Patologi Veteriner Patogenesis Dasar Penyakit Hewan. Proyeksi Indonesia. Sleman.

Song, Y., Joann, E. M., Jullie E.B., Howard, D.S., Simin, L., 2005. Association of Dietary Flavonoids With Risk of Type 2 Diabetes, and Markers Of Insulin Resistance and Systemic Inflammation In Woman: A Prospective Study and CrossSectional Analysis. Journal of The American College of Nutrition. 25(5).

Wolfenshn, S., dan Llpyd, M. 2013. Handbook of Laboratory Animal, Management and Walfare, 4th ed. Wileyblackwell. West sussex. 234.

Yanti, A.R., I. Rachmawati., N.A. Fentami., 2015. Petunjuk Praktikum Farmakologi. Esa Unggul. Jakarta. 